\title{
Cooperative Effort for Industrial Energy Data Collection (IEDC)
}

H.J. Green
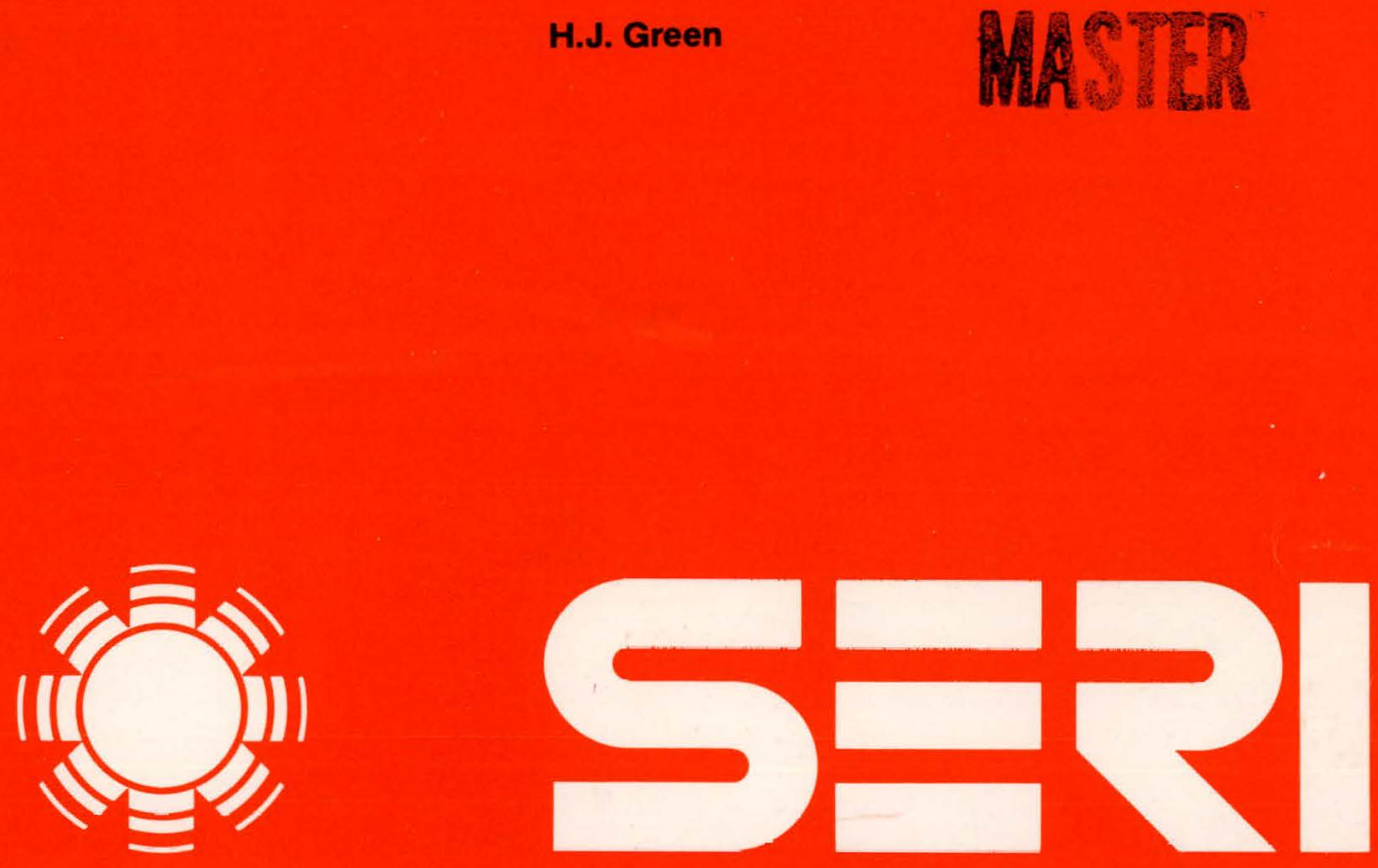

Solar Energy Research Institute

A Division of Midwest Research Institute

1536 Cole Boulevard

Golden, Colorado 80401

Operated for the U.S. Department of Energy under Contract No. EG-77-C-01-4042

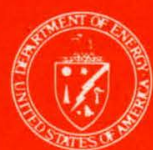




\section{DISCLAIMER}

This report was prepared as an account of work sponsored by an agency of the United States Government. Neither the United States Government nor any agency Thereof, nor any of their employees, makes any warranty, express or implied, or assumes any legal liability or responsibility for the accuracy, completeness, or usefulness of any information, apparatus, product, or process disclosed, or represents that its use would not infringe privately owned rights. Reference herein to any specific commercial product, process, or service by trade name, trademark, manufacturer, or otherwise does not necessarily constitute or imply its endorsement, recommendation, or favoring by the United States Government or any agency thereof. The views and opinions of authors expressed herein do not necessarily state or reflect those of the United States Government or any agency thereof. 


\section{DISCLAIMER}

Portions of this document may be illegible in electronic image products. Images are produced from the best available original document. 
Printed in the United States of America Available from:

National Technical Information Service

U.S. Department of Commerce

5285 Port Royal Road

Springfield, VA 22161

Price:

Microfiche $\$ 3.00$

Printed Copy $\$ 4.00$

$$
5.02
$$

\section{NOTICE}

This report was prepared as an account of work sponsored by the United States Government. Neither the United States nor the United States Department of Energy, nor any of their employees, nor any of their contractors, subcontractors, or their employees, makes any warranty, express or implied, or assumes any legal liability or responsibility for the accuracy, completeness or usefulness of any information, apparatus, product or process disclosed, or represents that its use would not infringe privately owned rights. 
SER I /RR-333-422

UC CATEGORY: UC-59B

COOPERATIVE EFFORT FOR

INDUSTRIAL ENERGY DATA

COLLECTION (IEDC)

H. J. GREEN

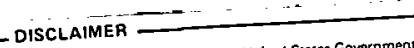

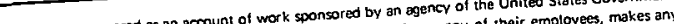
This book w unted States Government nol diny ogency the Neither the express or implied, or essumes any laga libatus, product, or process disclosed. Of

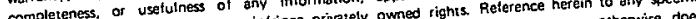

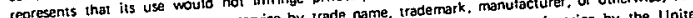
commercial product. process. ar a

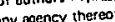

OCTOBER 1979

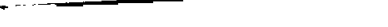

PREPARED UNDER TASK NO. 3422.4

\section{Solar Energy Research institute}

1536 Cole Boulevard

Golden, Colorado 80401

A Division of Midwest Research Institute

Prepared for the U.S. Department of Energy

Contract No. EG $\cdot 77 \cdot C \cdot 01 \cdot 4042$ 


\section{THIS PAGE}

\section{WAS INTENTIONALLY \\ LEFT BLANK}




\section{FOREWORD}

This report was prepared as part of Task 3422 within the Industrial Process Heat (IPH) Program at SERI. The initiative and leadership for the IEDC project was provided by Pete Ketels and Kenneth Brown. Douglas Hooker also has made important contributions to the effort.

Furthermore, this project has been supported by many solar energy researchers and contractors outside of SERI. Without their efforts, a coordination project of this magnitude would be impossible.

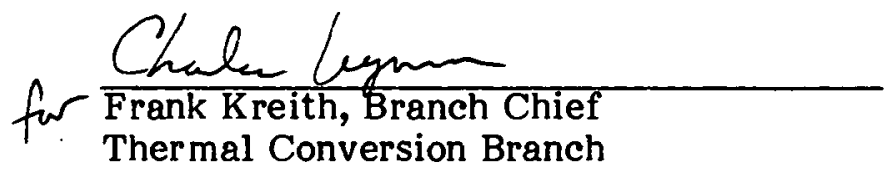

Approved for:

SOLAR ENERGY RESEARCH INSTITUTE

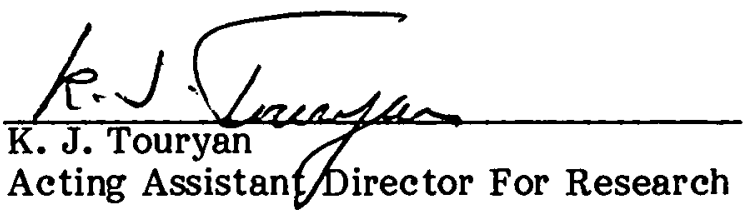




\section{THIS PAGE}

\section{WAS INTENTIONALLY \\ LEFT BLANK}




\begin{abstract}
The expanding research effort in recent years in industrial energy use has created a need for detailed data on specific industrial processes. To meet this need and eliminate multiple contacts with individual plants, a cooperative effort to collect and centralize industrial energy use data has been organized by several solar research organizations. To date, a centralized list has been produced of industrial plants and trade associations that have been contacted, and a data format has been created for use by all organizations interested in participating in this effort.
\end{abstract}




\section{THIS PAGE}

WAS INTENTIONALLY

$\therefore \quad \mathbb{E F T} B L A N \mathbb{K}$ 


\section{TABLE OF CONTENTS}

$\underline{\text { Page }}$

$1.0 \quad$ An Introduction to the $\operatorname{IEDC} \ldots \ldots \ldots \ldots \ldots \ldots \ldots \ldots \ldots \ldots \ldots \ldots \ldots \ldots$

1.1 The Need for a Cooperative Data Gathering Effort $\ldots \ldots \ldots \ldots \ldots \ldots \ldots$.

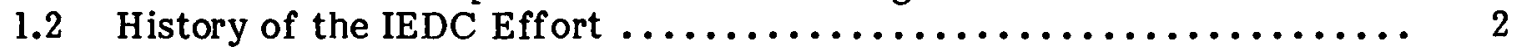

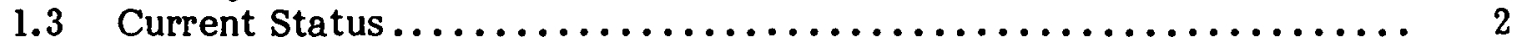

$2.0 \quad$ Agreements $\ldots \ldots \ldots \ldots \ldots \ldots \ldots \ldots \ldots \ldots \ldots \ldots \ldots \ldots \ldots \ldots \ldots \ldots \ldots \ldots$

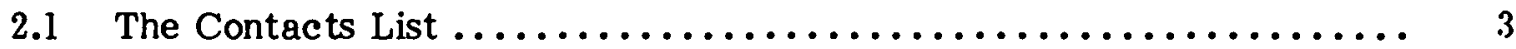

2.2 Data Format and Central File....................... 3

$3.0 \quad$ A Final Word $\ldots \ldots \ldots \ldots \ldots \ldots \ldots \ldots \ldots \ldots \ldots \ldots \ldots \ldots \ldots \ldots \ldots \ldots \ldots \ldots$

$4.0 \quad$ Ref erences $\ldots \ldots \ldots \ldots \ldots \ldots \ldots \ldots \ldots \ldots \ldots \ldots \ldots \ldots \ldots \ldots \ldots \ldots \ldots$

Appendix: Major Industrial Energy Studies Since $1974 \ldots \ldots \ldots \ldots \ldots \ldots \ldots \ldots \ldots$

\section{LIST OF TABLES}

2-1 Sample Page of Contacts List: Industrial Contacts .............. 4

2-2 Sample Page of Contacts List: Trade Associations Contacts ......... 5

2-3 Data Format: Industrial Process Energy Data ................. 6 


\section{SECTION 1.0}

\section{AN INTRODUCTION TO THE IEDC}

\subsection{THE NEED FOR A COOPERATIVE DATA GATHERING EFFORT}

Industry, the nation's largest energy end-use sector, has received much attention from energy researchers in recent years. There is great potential within this sector for saving fossil fuels through the use of conservation practices and/or renewable energy resources. Quantities of data are available concerning the amounts of fuels and electricity used by specific industries in various parts of the country $[1,2,3]$. This information has been a great help in understanding the challenge of supplying energy to the nation's industries in an era of diminishing fossil fuel resources; however, it is not adequate for many current research efforts. In order to apply a new energy technology to an industrial process, specific data for the process must be known. This data may include process temperatures, heat transport medium conditions (e.g., temperature, flow rate, pressure), peak electrical power, supply voltages, process schedules, etc. In addition, specific information about the plant, such as location, company investment criteria, management attitudes toward renewable resources, and regulatory restrictions, is of ten useful in resource and market evaluation.

In the past few years, several studies have been carried out to accumulate this kind of plant-specific data. These studies originated in several federal programs, including those for industrial energy conservation, environmental assessments, geothermal energy, and solar energy (industrial process heat, small power systems, and cogeneration). Although the studies were largely independent of one another, much of the data collected were similar enough to be useful for multiple programs.

Cooperative collection of this large amount of data is expedient for several reasons. First, the laboratories and subcontractors gathering this data have limited resources. A cooperative effort maximizes the return on these resources by minimizing duplication of efforts. A comprehensive, centralized data file would make more data available to a given research group than they could accumulate on their own. Second, the continuing interest and good will of the industrial community, important to both research and future commercialization activities, is at stake. Industries already are burdened with requests for information from many government agencies. It is in the best interest of the research community to recognize the inconveniences caused by these requests and to eliminate, if possible, multiple contacts with individual companies or plants. Third, extensive data requirements in any one study may demand the use of large-scale surveys. However, surveys (by definition, inquiries in which the same questions are asked of nine or more respondents) by a government agency or contractor must be approved by the Office of Management and Budget. Approval can be difficult to obtain and the content and length of each survey is carefully regulated.

A large-scale survey of industrial energy use is being planned by the Energy Information Agency of the Department of Energy (Consumption Data Studies Division). This survey, however, will be two to four years in the making and its contents have not yet been determined. 


\subsection{HISTORY OF THE IEDC EFPORT}

During 1978, it became apparent that a cooperative data gathering effort was needed. As a result of the efforts of many individuals, an organizational meeting was held on November 29 and 30, 1978, at the Aerospace Corporation in Los Angeles, Calif. This meeting brought together 17 individuals representing 12 organizations. The meeting resulted in an awareness of past and current data gathering activities of the various organizations, an outline of a proposed data format to be used in common for future data gathering efforts, and agreements concerning the gathering and centralizing of data.

The primary agreement related to data gathering was that all contacts with industrial plants or trade associations would be entered on a master list and distributed to all IEDC (Industrial Energy Data Collection) members. All available data would be compiled in a common format and submitted to a central data file made available to all members. It was agreed that the Solar Energy Research Institute (SERI) wnuld he the central point for assembly and distribution of this information. Following the organizational meeting, each member was asked to submit to SERI any further comments on the proposed data format. From these inputs, a committee at SERI (including engineers, market analysts, and computer scientists) prepared the data format. This format, along with the first edition of the Contacts Lists, was distributed to all interested parties in January 1979.

From the beginning, it has been recognized that the IEDC is a voluntary effort. There are no binding agreements; its success depends entirely on the cooperation of the members. A "member," then, is any interested group doing work related to industrial energy use willing to abide by the IEDC agreements.

\subsection{CURRENT STATUS}

Nearly a year after its inception, the IEDC continues to interest many individuals. At the present time, nearly thirty organizations are on the IEDC distribution list. It is clear that the IEDC has the potential to meet a great need for information in the field of industrial process encrgy analysis.

The main function of the IEDC in the past months has been the maintenance of an updated Contacts List. The List, now in its third revision, contains entries from five organizations representing seven different studies. There are 39 entries for trade associations and 150 entries for industrial plants. No data is yet on file. 


\section{SECTION 2.0}

\section{AGREEMENTS}

\subsection{THE CONTACTS LIST}

The Contacts List is a record of contacts by IEDC members with industrial plants and trade associations. The main goal of the List is to reduce multiple contacts with individual industrial plants. Contacts with trade associations are recorded chiefly for informational purposes. The Contacts List is intended for distribution to IEDC members with ongoing or planned data gathering activities.

All IEDC members that have completed studies are asked to submit to SERI a list of the industrial plants and trade associations they contacted, both those participating in the study and those declining involvement. It is understood that entries may not necessarily be complete. At the discretion of the contacted party, a given entry may be wholly or partially edited to maintain anonymity. If at all possible, at least the SIC (Standard Industrial Classification) code and the state are included in the entry.

At SERI, the individual lists are combined into one master list representing the composite efforts of the IEDC. The list is put in numerical order by SIC code, then in alphabetical order by state and by city; thus, information accumulated on a particular industry in various parts of the country can be determined. Because each entry is keyed to the person who submitted it, it is possible to learn from the contributor which companies did and did not participate and what data, if any, are available (see Tables 2-1 and 2-2).

The agreements concerning the Contacts List are:

- IEDC members who have made contacts with industries or trade associations will submit to SERI a list of these contacts, edited as necessary and in the appropriate form at.

- IEDC members undertaking new studies will refer to the Contacts List and try, when possible, to avoid multiple contacts and to use data already available.

- SERI will maintain the Contacts List and make it available to IEDC members as nẹerier.

\subsection{DATA FORMAT AND CENTRAL FUE}

The data format, originating from the organizational meeting in Los Angeles, is an extensive form at that reflects the composite needs of $m$ any research interests. It includes plant identifiers, process heat and electric power use, plant schedules, and economic and institutional factors (see Table 2-3). It is not intended or expected that all this data will be collected during a visit. with a given plant. The data format serves as a guide to what data can be used if it can possibly be obtained.

At SERI, data submitted by various IEDC members will be combined into one central data file. The data will be made available to all interested parties. Data will be stored initi ally in hard copy and on word processing discs. As the size of the central file and user needs dictate, data may be entered in a computer data base. As with the Contacts List, some of the data may be proprietary. Such entries may be edited. 
Table 2-1. SAMPLE PAGE OF CONTACTS LIST: INDUSTRIAL CONTACTS

\begin{tabular}{|c|c|}
\hline $\begin{array}{ll}\text { SIC CODE: } & 2821-\text { Plastics } \\
\text { STATE: } & \text { TX } \\
\text { COMPANY: Rexene/Dart Industries } \\
\text { CONTACT: R.S. Rennicks, Dir., } \\
\text { Engr. and Construction } \\
\text { TYPE OF INTERVIEW: } \\
\text { CONTACTED BY: } \# 3\end{array}$ & $\begin{array}{l}\text { CITY: Odessa } \\
\text { PLANT: } \\
\text { PHONE: }\end{array}$ \\
\hline $\begin{array}{l}\text { SIC CODE: } 2834 \text { - Pharmaceutical } \\
\text { STATE: CA } \\
\text { COMPANY: Arion } \\
\text { CONTACT: } \\
\text { TYPE OF INTERVIEW: Letter and Telecon } \\
\text { CONTACTED BY: } \quad \# 3\end{array}$ & $\begin{array}{l}\text { CITY: } \\
\text { PLANT: } \\
\text { PHONE: }\end{array}$ \\
\hline $\begin{array}{l}\text { SIC CODE: } 2834 \text { - Pharmaceuticals } \\
\text { STATE: NJ } \\
\text { COMPANY: Squibb } \\
\text { CONTACT: Michael J. Vereb, Dir. } \\
\quad \text { Oper. Plan \& Engr. } \\
\text { TYPE OF INTERVIEW: } \\
\text { CONTACTED BY: \#4 }\end{array}$ & $\begin{array}{l}\text { CITY: New Brunswick } \\
\text { PLANT: } \\
\text { PHONE: }\end{array}$ \\
\hline $\begin{array}{l}\text { SIC CODE: } 2834 \text { - Pharmaceuticals } \\
\text { STATE: NJ } \\
\text { COMPANY: } \\
\text { CONTACT: V.P., Technical Operations } \\
\text { TYPE OF INTERVIEW: } \\
\text { CONTACTED BY: } \# 4\end{array}$ & $\begin{array}{l}\text { CITY: } \\
\text { PLAN'T: } \\
\text { PHONE: }\end{array}$ \\
\hline $\begin{array}{ll}\text { SIC CODE: } & 2841-\text { Soaps and Detergents } \\
\text { STATE: } & \text { CA } \\
\text { COMPANY: Purex } \\
\text { CONTACT: Lyle S. Lofdahl, } \\
\quad \text { Senior Vice Pres. } \\
\text { TYPE OF INTERVIEW: } \\
\text { GONTACTED BY: \#4 }\end{array}$ & $\begin{array}{l}\text { CITY: Lakewood } \\
\text { PLANT: } \\
\text { PHONE: }\end{array}$ \\
\hline $\begin{array}{l}\text { SIC CODE: } 2841 \\
\text { STATE: } \quad \text { KS } \\
\text { COMPANY: Procter \& Gamble Mfg. Co. } \\
\text { CONTACT: } \\
\text { TYPE OF INTERVIEW: Telecon } \\
\text { CONTACTED BY: } \# 5\end{array}$ & $\begin{array}{l}\text { CITY: Kansas City } \\
\text { PLANT: Kansas City, KS } \\
\text { PHONE: }\end{array}$ \\
\hline
\end{tabular}




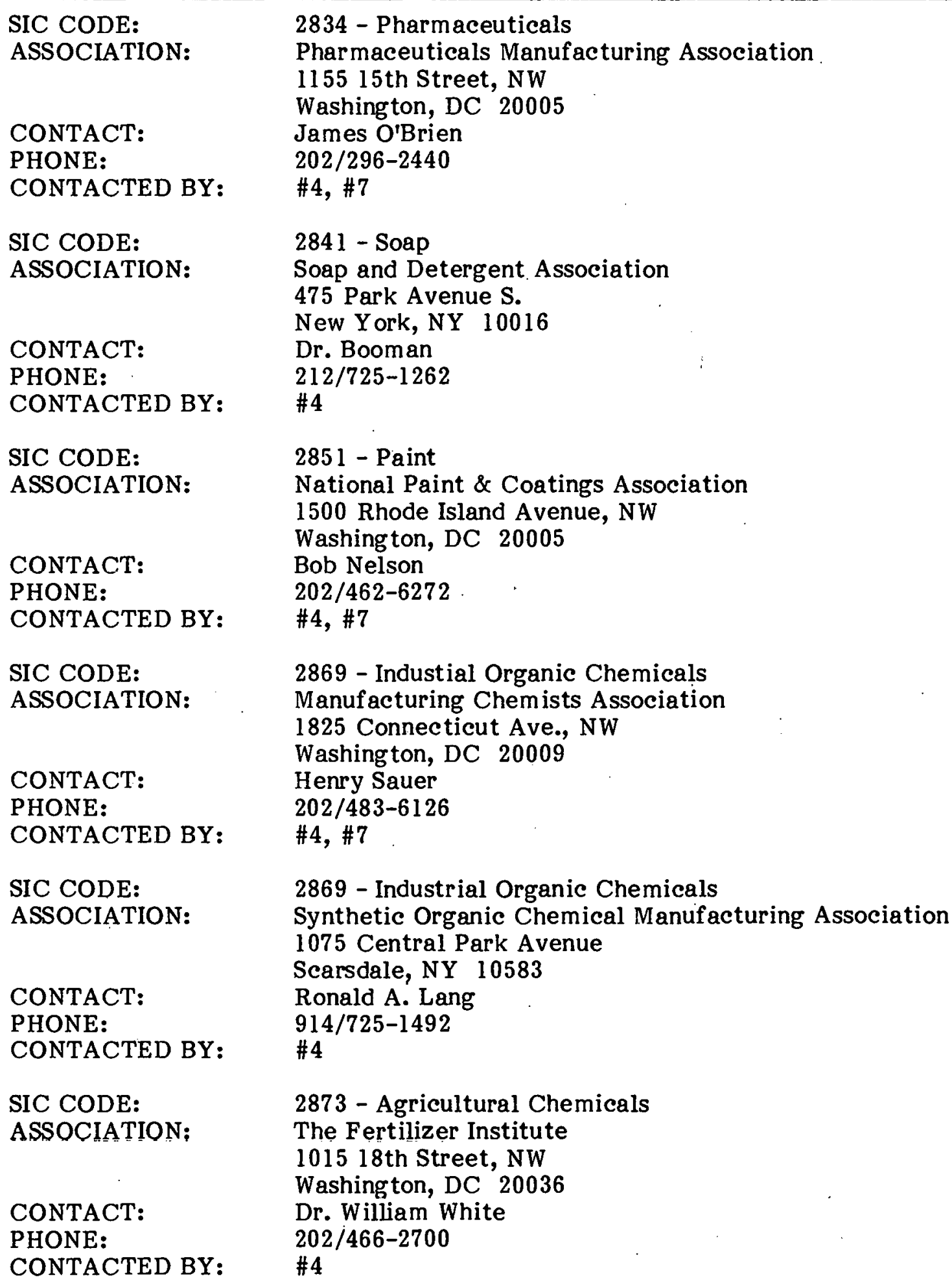

SIC CODE:

ASSOCIATION:

CONTACT:

PHONE:

CONTACTED BY:

SIC CODE:

ASSOCIATION:

CONTACT:

PHONE:

CONTACTED BY:

SIC CODE:

ASSOCIATION:

CONTACT:

PHONE:

CONTACTED BY:

SIC CODE:

ASSOCIATION:

CONTACT:

PHONE:

CONTACTED BY:

SIC CODE:

ASSOCIATION:

CONTACT:

PHONE:

CONTACTED BY:

SIC CODE:

ASSOCIATION;

CONTACT:

PHONE:

CONTACTED BY:

\section{4 - Pharmaceuticals}

Pharmaceuticals Manufacturing Association.

115515 th Street, NW

Washing ton, DC 20005

James O'Brien

202/296-2440

\#4, \#7

2841 - Soap

Soap and Detergent Association

475 Park Avenue S.

New York, NY 10016

Dr. Booman

$212 / 725-1262$

\#4

2851 - Paint

National Paint \& Coatings Association

1500 Rhode Island Avenue, NW

Washing ton, DC 20005

Bob Nelson

202/462-6272

\#4, \#7

2869 - Industial Organic Chemicals

Manuf acturing Chemists Association

1825 Connecticut Ave., NW

Washing ton, DC 20009

Henry Sauer

202/483-61 26

\#4, \#

2869 - Industrial Organic Chemicals

Synthetic Organic Chemical Manufacturing Association

1075 Central Park Avenue

Scarsdale, NY 10583

Ronald A. Lang

914/725-1492

\#4

2873 - Agricultural Chemicals

The Fertilizer Institute

101518 th Street, NW

Washington, DC 20036

Dr. William White

202/466-2700

\#4 
Table 2-3. DATA FORMAT: INDUSTRIAL PROCESS ENERGY DATA

1.0 Plant Identifiers

\begin{tabular}{ll}
\hline 1.1 & SIC code \\
1.2 & City \\
1.3 & State \\
1.4 & Zip code \\
1.5 & Company ufme \\
1.6 & Plant name \\
1.7 & Plant contact \\
1.8 & Phnne numnher \\
1.9 & Interviewer/firm \\
1.10 & Phome number
\end{tabular}

2.0 Process Heat Requirements

Units

Indivlulul Procusses (up to flve)

2.1 Name of process

2.2n Supply tomperature

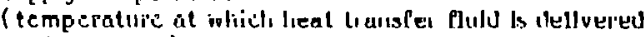
(1) (lie process)

2.2b Return tenuprature (tomperature at which heat transfer fluid leaves process)

2.3 Materinl temperature

2.4 How rate

$\% .5$ pressure

2.6 Stean quality

2.7 Hent trnnsport medium $(\text { code })^{\mathrm{a}}$

2.8 proess medium $(\operatorname{cote})^{n}$

2.9 Do ily stnit hour

2.10 Daily and !our

2.11 Days ner week

2.12 Scheduled downt ime (code)

2.13 Unsclieduled downtimc

2.14 Process line condition (excellent, good, average, (air, or poor)

Plant Totals

2.15 Unscheduled dowritime

2.16 Finel type

(code)

Q.17 Alúlitíl für nasuy

2.18 Cost

2.IY IItility suruly scliedule

(interruptible or continuous: I or C)

Dlseuss:

2.20 Baokup fuọl

2.21 Substitutnbility

$\begin{aligned}{ }_{\mathbf{a}_{A}}=\text { air } & S=\text { steam } \\ W=\text { water } & U=\text { other }\end{aligned}$

$\mathrm{b}_{\mathrm{NN}} \mathrm{NN}$ (last week of operation - weok operation resumes)

Example: If plant closes from Christmas to New Year's Day, tlie code is: $51-01$.

${ }^{\mathrm{C}} \mathrm{C}=$ coal

$\mathbf{R}=$ residual oil

$G=$ natural gas

$D=$ distilled oi

$\mathbf{P}=$ propante

weeks/yr

Mintii/gr:

$\$ /$ MBtu 


\section{Table 2-3. DATA FORMAT: INDUSTRIAL PROCESS ENERGY DATA (concluded)}

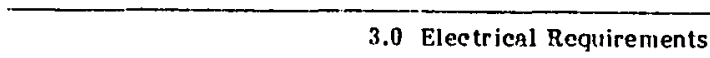

Ench Process (up to five)

3.1 Peak power

3.2 reak/average ratio

3.3 Supply voltage

Units

Each On-Site Turbine-Generntor Unit (up to five)

$3.4 \quad$ Fucl lype

3.5 Turbo-generator type

(dicsel, stcam, gas turbine, or other: D,s, $\mathrm{G}$, or $\mathrm{O}$ )

$3.6 \quad$ Pantra enpncity

$3.7 \quad$ Inlet temperature

Stenm Systems Only

$3.8 \quad$ Inlet pressure

3.9 Flow rate

3.10 Extraction teinperature

3.11 Extruction pressure

Plent Totals

3.12 Ulility tompunty

3.13 Rute schedule

(utility-designnted rate code if avoilable)

3.14 Total annual purchased power

3.15 Total annual self-gerierated power MWh

MWh

3.16 Estimated unit cost of self-generated power milsikivh

\begin{tabular}{|c|c|c|}
\hline & 4.0 Eeonornic Factors & Units \\
\hline 4.1 & Discount rate & *ै \\
\hline 4.2 & Payback period & yr \\
\hline 4.3 & Number of employees & \\
\hline 4.4 & Value of shipments & $\$ 10^{6} / \mathrm{yr}$ \\
\hline 4.5 & Age of plant & $\mathrm{yr}$ \\
\hline 4.6 & Percentage of opernting cost for energy & $\%$ \\
\hline 4.7 & $\begin{array}{l}\text { Total available udjacent land } \\
\text { (own, lease, purchase) }\end{array}$ & acres \\
\hline 4.8 & 'Total available roof area & $10^{3} \mathrm{ft}^{2}$ \\
\hline 4.9 & $\begin{array}{l}\text { Urban or rural location } \\
\text { (U or } R \text { ) }\end{array}$ & \\
\hline \multicolumn{3}{|c|}{ Discuss } \\
\hline 4.10 & Shape, terrain, and suitability of available land & \\
\hline 4.11 & $\begin{array}{l}\text { Plant environinent } \\
\text { (dust, air pcllutants, local nicro-climate, etc.) }\end{array}$ & · \\
\hline 4.12 & Other considerations (if any) & \\
\hline \multicolumn{3}{|c|}{5.0 Institutional Factors } \\
\hline 5.1 & Perspectives on fuel availability & \\
\hline 5.2 & Perspectives on fuel costs & \\
\hline 5.3 & Environmental impact probleins & \\
\hline 5.4 & Necessary conditions before use of solar encrgy is considered & \\
\hline 5.5 & Does an energy management prograin/comınittee exist? & \\
\hline 5.6 & $\begin{array}{l}\text { Preferred incentives } \\
\text { (tax credit, low-interest loans) }\end{array}$ & \\
\hline 5.7 & Who is responsible for energy-related investment? & \\
\hline 5.8 & $\begin{array}{l}\text { Prefercert malhrets of informatinn dissemination } \\
\text { (trade journals, technical mcetings, trute associations, briefings, or other) }\end{array}$ & \\
\hline 5.9 & Fnorgy conservation measures implemented (since 197.1) & \\
\hline 5.10 & What alternntives have been eunsidered? & \\
\hline
\end{tabular}

kVA 
The agreements concerning the central data file are:

- IEDC members will endeavor to gather as much of the information specified in the data form at as time and resources allow.

- The data will be submitted to SERI in the appropriate format and edited as necess ary.

- SERI will compile a central duta file of all contributions and make it available to all interested parties. 


\section{SECTION 3.0}

\section{A FINAL WORD}

Evolving government programs in industrial energy analysis, particularly those for solar energy and conservation, rely on accurate and detailed information on many aspects of industrial energy use. The IEDC effort represents an independent and voluntary commitment to fulfilling this need. While voluntary commitment to data collection and assimilation may have limited effectiveness, the past year's activity points clearly to the advantages of awareness among researchers in related fields of each other's efforts. Studies and plans for studies, which may go unrecognized in the ordinary course of interlaboratory communication, are now specifically highlighted by this effort. The close relationship of programs as apparently disparate as geothermal energy utilization and solar thermal power is also revealed, illustrating the common bond of all programs aiming at industrial energy substitution. Cooperation in industrial energy analysis is much needed, and SERI is confident that most participants will find this project rewarding.

The extent to which the IEDC effort can be successfully carried out depends on many factors beyond our ability to project at this time. This report is intended as a summary of activity to date and as an outline of participatory responsibilities of prospective members. Implementation of plans for the IEDC data base will be pursued and update reports will be issued. 
S=PI 


\section{SECTION 4.0}

\section{REFERENCES}

1. Survey of the Applications of Solar-Thermal Energy Systems to Industrial Process Heat. 3 vol. Columbus, OH: Battelle Columbus Labs.; January 1977; Report No. TID27348/1-3.

2. InterTechnology Corp. Analysis of the Economic Potential of Solar Thermal Energy to Provide Industrial Process Heat. 3 vol. Warrenton, VA: InterTech. Corp.; February 1977; Report No. COO/2829-76/1.

3. U.S. Department of Commerce. Bureau of the Census. Annual Survey of Manufacturers, Fuels and Electric Energy Consumed. 1972. 


\section{SEPI}




\section{APPENDIX}

\section{MAJOR INDUSTRIAL ENERGY STUDIES}

SDNCE 1974

\begin{tabular}{l} 
Date of \\
Publication \\
\hline
\end{tabular}

Compary or

Laboratory

July 1974

April 1975

April 1975

$\varpi$ Inc.
Development Planning and Research Assoc.,

Drexel University

MeDonnel Douglas

Astrongutics Corp.

$\begin{array}{ll}\text { November } 1976 & \text { Johns-NIanville Corp } \\ \text { November } 1976 & \text { Johns-Nanville Corp } \\ \text { January } 1977 & \begin{array}{l}\text { Battelle Columbus } \\ \text { Laboratories }\end{array}\end{array}$

\section{$\underline{\text { Title }}$}

Industrial Energy Study of Selected Food Industries

Utilization Analysis of Energy Systems - Food Processing Industry: Campbell Soup Plant \#2

\section{Industrial Applications} of Solar Ther mal Total Energy

A Study of Energy Conservation Potential in the Meat Packing Industry

\section{A Study of Energy Conservation Potential in the Baking Industry}

Survey of the Applications of Solar Thermal Energy Systems to Industrial Process Heat
Industries

Studied

Various food industries

Tomato \& vegetable juice

Food; paper products; chemicals \& applied products; fabricated metal products; stone, clay, \& glass; petroleum \& coal products

Meatpacking

Baked goods 
Date of

Publication

February 1977

April 1977

March 1978

March 1978

Jet Propulsion

Laboratory

\section{Title}

Analysis of the Economic

Potential of Solar Thermal

Energy to Provide

Industrial Process Heat

Drexel University

Aerospace Corp.

Latoratory

October 1978 Lawrence Iivermore

Latoratories

December $1978 \quad$ Aerospace Corp.
Energy Utilization Analysis, Chesterton Poultry Plant, Campbell Soup Company

High-Temperature Industrial Process Heat

Solar Applications in the Commercial, Industrial \& Agricultural Sectors of California

Solar Energy for Process Heat: Design and Cost Studies of Four Industrial Retrofit Applications

Limiting Factors for the Near Term Potential of Solar Industrial Process Heat

Field Survey of Solar Total Energy Systems, Potential Industrial Applications
Industries

Studied

Poultry processing

Primary metals; paper \& pulp; stone, clay, \& glass

Food processing, agricultural process heat, commercial process heat, paper production lumber, soap production, vehicle manufacturing, plastics, metal plating, concrete products

Vegetable oils, soap manufacturing, paper production, fluid milk, brewing

Frasch sulfur mining, fruit packing, borax, potash refining

Sugar refining; paperboard mills; plastics; pharmaceuticals, soaps, \& detergents; industrial organic chemicals; agricultural chemicals 
Date of

Publication

December 1978

December 197B

January 1979

July 1979

October 1979

로
Company or

Laboratory

Purdue University

Purdue University

Jet Prcpulsion

Laboratory

Aerospace Corp.

Solar Energy

Research Institute

Forthcoming

Fortheoming

\section{Research Institute}

Solar Energy

\section{Title}

Energy Utilization in a Dairy Processing Plant

\section{Energy Utilization in Meat Processing Plants}

Potential for Cogeneration of Heat and Electricity in California Industry

Solar Thermal Small Power Systems Study

End-Use Matching for Solar Industrial Process Heat.

Industrial Process Heat Case Studies Research Institute

Analysis of Industries with Potential for Solar IPH
Industries

$\underline{\text { Studied }}$

Fluid milk

Meat packing

Paperboard, cement, petroleum, food, steel, chemicals, pulp \& paper, timber, sugar beets

Comprehensive survey of on-site electric geerating units in U.S. industry $\left(<10 \mathrm{MW}_{\mathrm{e}}\right)$

Various industries in six cities

Bakery, meatpacking, fluid milk, petroleum production \& refining, paints

Dairies, paint resin manufacturing, die-casting, wet-corn milling, petroleum refining, bakeries 


\begin{tabular}{|c|c|c|}
\hline $\begin{array}{l}\text { Document Control } \\
\text { Page }\end{array}$ & \begin{tabular}{|l|l|} 
1. SERI Report No. & 2. NTIS Accession No. \\
RR-333-422 & \\
\end{tabular} & 3. Recipient's Accession No. \\
\hline \multirow{2}{*}{\multicolumn{2}{|c|}{$\begin{array}{l}\text { 4. Title and Subtitle } \\
\text { The Cooperative Effort for Industrial Energy Data }\end{array}$}} & $\begin{array}{l}\text { 5. Publication Date } \\
\text { October } 1979 \\
\end{array}$ \\
\hline & & 6. \\
\hline \multicolumn{2}{|l|}{$\begin{array}{l}\text { 7. Author(s) } \\
\text { H.J. Green }\end{array}$} & 8. Performing Organization Rept. No. \\
\hline \multirow{2}{*}{\multicolumn{2}{|c|}{$\begin{array}{l}\text { 9. Performing Organization Name and Address } \\
\text { Solar Energy Research Institute } \\
1617 \text { cole Blvd. } \\
\text { Golden, Colo. } 80401\end{array}$}} & $\begin{array}{l}\text { 10. Project/Task/Work Unit No. } \\
3422.4\end{array}$ \\
\hline & & $\begin{array}{l}\text { 11. Sontract (G) ar Grant (G) No } \\
\text { (C) } \\
\text { (G) }\end{array}$ \\
\hline \multirow{2}{*}{\multicolumn{2}{|c|}{ 12. Sponsoring Organization Name and Address }} & $\begin{array}{l}\text { 13. Type of Report \& Period Covered } \\
\text { Research Report. }\end{array}$ \\
\hline & & 14. \\
\hline \multicolumn{3}{|l|}{ 15. Supplementary Notes } \\
\hline \multicolumn{3}{|c|}{$\begin{array}{l}\text { 16. Abstract (Limit: } 200 \text { words) } \\
\text { The expanding research effort in recent years in industrial energy use has created } \\
\text { a need for detailed data on specific industrial processes. To meet this need } \\
\text { and eliminate multiple contacts with individual plants, a cooperative effort to } \\
\text { collect and centralize industrial energy use data has been organized by several } \\
\text { solar research orqanizations. To date, a centralized list has been produced of } \\
\text { industrial plants and trade associations that have been contacted, and a data } \\
\text { format has been created for use by all organizations interested in participating } \\
\text { in this effort. }\end{array}$} \\
\hline \multirow{3}{*}{\multicolumn{3}{|c|}{$\begin{array}{l}\text { 17. Document Analysis } \\
\text { a. Desuinluis } \\
\text { Enerq.y Consumption ; Datta Compilation ; Dat.a Arquisitionn ; Industry ; } \\
\text { Industrial Process Heat ; Data ; Coordinated Research Programs } \\
\text { b. Identifiers/Open-Ended Terms }\end{array}$}} \\
\hline & & \\
\hline & & \\
\hline \multirow[t]{2}{*}{ :8. Availability Statement } & \multirow{2}{*}{$\begin{array}{l}\text { NTIS, U. S. Dept. of Commerce } \\
5285 \text { Port Royal Road } \\
\text { Springfield, VA } 22161\end{array}$} & $\begin{array}{c}\text { 19. No. of Pages } \\
24\end{array}$ \\
\hline & & \begin{tabular}{|r|r|}
20. & Price \\
& $\$ 4.00$
\end{tabular} \\
\hline
\end{tabular}

